\title{
Protect with Plywood ${ }^{1}$
}

ABE376

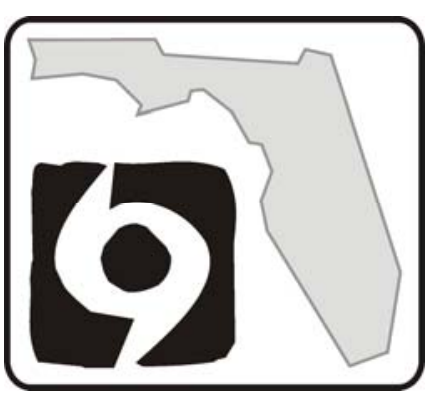

Hal S. Knowles, III, Kathleen C. Ruppert, Karla A. Lenfesty and Barbara Haldeman ${ }^{2}$

Proper storm protection requires time and money. When time is too short to hire a commercial contractor or if costs must remain low, properly installed plywood shutters can provide reasonable protection for your house.

Due to the temporary nature of plywood shutters, the panel weight, and the installation labor required, we recommend using them as a last resort. Pick up our "Install Window Shutters" document to review other options.

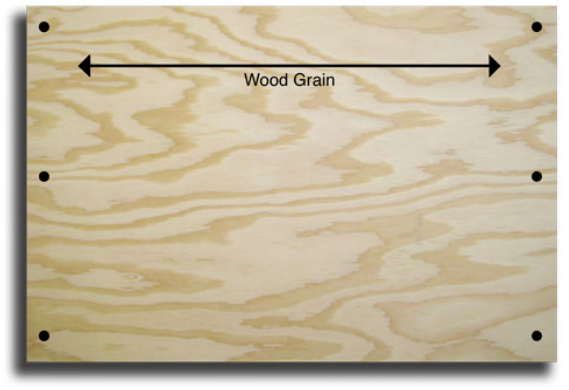

Plywood is strongest in the direction of its wood grain. Source: Institute for Business \& Home Safety

\section{Are All Plywood Shutters the Same?}

NO. There are many ways to install plywood shutters. However, we suggest you use one of two main methods. For concrete block homes with windows inset two or more inches from the exterior wall, we recommend using barrel bolt plywood shutters. Overlapping plywood shutters are best for windows that are inset less than two inches.

\section{Barrel Bolt Plywood Shutters}

Needed Materials:

- Minimum 5/8 inch thick plywood (3/4 inch is recommended)

- 3- or 4-inch barrel bolts

- Drill

- Circular saw

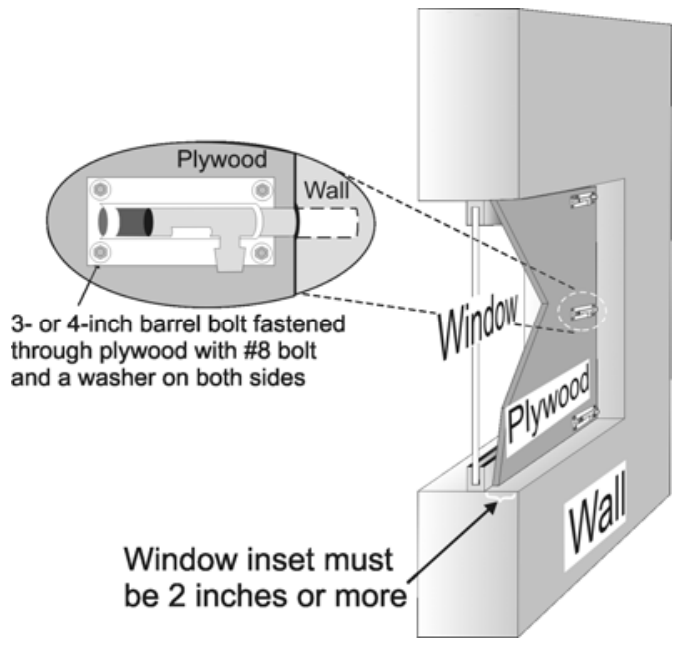

Basic Installation Directions:

Cut plywood to fit snugly in each window indentation. Connect multiple sheets with $2 \times 4$ s or sturdy hinges for large openings. Screw barrel bolts to each plywood shutter, using one bolt for every 12 inches of vertical plywood. Mark location for bolt holes in the wall. Label each panel with "Top" and "Bottom" and the window it fits. Drill holes. Plug the holes when not in use.

1. This document A BE 376 is Part 3 of 5 in the Education + Action = Wind Damage Mitigation series. Publication date: November 2005.

2. Hal S. Knowles, III, Coordinator, Program for Resource Efficient Communities; Kathleen C. Ruppert, Associate Extension Scientist, Florida Energy Extension Service; Karla A. Lenfesty, Windstorm Damage Mitigation Program Specialist, St. Lucie County Cooperative Extension, Institute of Food and Agricultural Sciences, University of Florida; Barbara Haldeman, Editorial Assistant, Florida Energy Extension Service.

The Institute of Food and Agricultural Sciences (IFAS) is an Equal Employment Opportunity - Affirmative Action Employer authorized to provide research, educational information and other services only to individuals and institutions that function without regard to race, creed, color, religion, age, disability, sex, sexual orientation, marital status, national origin, political opinions or affiliations. For information on obtaining other extension publications, contact your county Cooperative Extension Service office. Florida Cooperative Extension Service / Institute of Food and Agricultural Sciences / University of Florida / Larry R. Arrington, Dean.

Publication partially funded from a Florida Department of Community Affairs Residential Construction Mitigation Program Grant. 


\section{Overlapping Plywood Shutters}

Needed Materials:

- Minimum 5/8 inch thick plywood (3/4 inch is recommended)

- Nails (less secure) or screws/bolts (more secure) at least 2 inches long

- Lead or stainless-steel sleeve wall anchors (do NOT use plastic)

- Hammer (for nails) and/or drill (for screws)

- Wood shims (if necessary)

- Circular saw

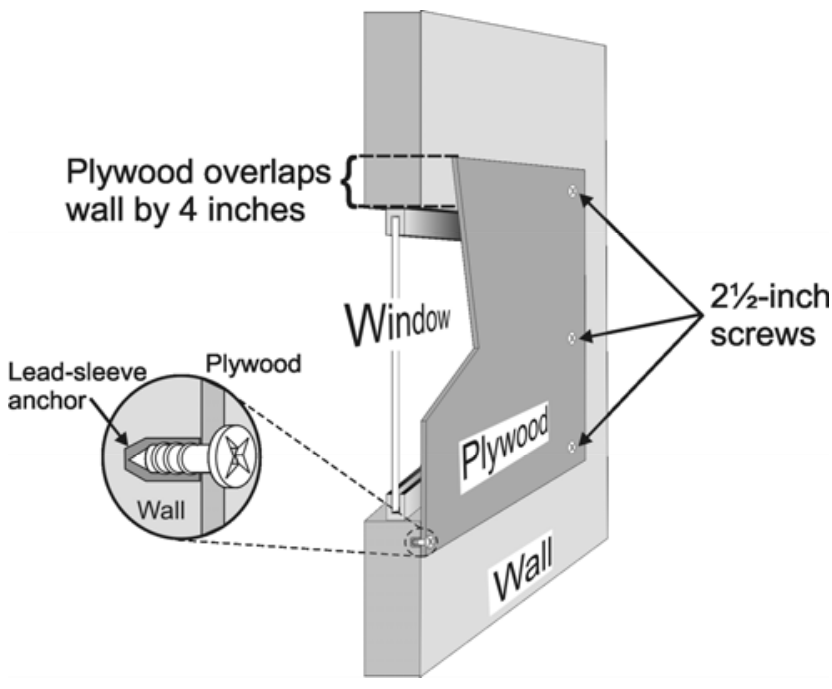

Basic Installation Directions:

Cut plywood to overlap each window opening by 4 inches or more. Connect multiple sheets with $2 \times 4 \mathrm{~s}$ or sturdy hinges for large openings. Drill matching holes through the plywood and the wall. Label each panel with "Top" and "Bottom" and the window it fits. Hammer sleeve anchors into wall holes. Screw (or bolt) plywood into the anchors. Plug the holes when not in use.

\section{Additional Issues to Consider}

Avoid OSB: It takes 30\% thicker oriented strand board (OSB) to equal the impact strength of plywood. We recommend using plywood.

Plan Ahead: Plywood is cheap, convenient, and available at most hardware stores. However, buy your plywood before a storm approaches. If you wait until the last minute your local hardware store may run out.
Store Properly: Plywood requires proper storage to prevent wood damage. Florida's hot humid climate can warp or degrade plywood making the shutter unusable. It is best to waterproof your plywood shutters with a sealant or paint and store them in a cool, dry place. Keep the shutter hardware (the bolts and screws) in a labeled container with the shutters. Storing plywood flat may also help prevent warping. Never store wet plywood.

Watch Out for Termites: Additionally, choose a storage location that keeps the plywood shutters off the ground. This will help reduce the potential for termite damage.

Label the Shutters: Most homes have a variety of window types and sizes. It is important to clearly mark each of your plywood shutters so you know which window it fits and which side is up. You may consider making a drawing of your house and marking each window on it with a special number to match your shutter labels.

For more detailed guidelines on a variety of plywood shutter designs, visit the APA (Engineered Wood Association) Web site (see below). Click on their "Publications" page and search for "hurricane shutters."

\section{Other Resources}

APA - The Engineered Wood Association www.apawood.org

NOAA \& AOML | Plywood Hurricane Shutters http://www.aoml.noaa.gov/hrd/shutters/index2.html 